\title{
The Potential of Charcoal Gasification as an Eco- Friendly Fuel
}

\author{
Aria Yopianita ${ }^{1, *}$ Aida Syarif ${ }^{2}$, Muhammad Yerizam²
}

\author{
${ }^{1}$ Master of Applied Renewable Energy Engineering, Sriwijaya State Polytechnic \\ ${ }^{2}$ Chemical Engineering, Sriwijaya State Polytechnic \\ *Corresponding author. Email: ayopianita01@gmail.com
}

\begin{abstract}
The use of coal as primary energy in Indonesia will continue to be carried out, although slowly it will experience a significant decline until 2050 by the mandate of the National Energy Policy and the General National Energy Plan; this is more or less due to the potential of national coal reserves of 38.84 Billion Tons. However, planning for green coal or clean coal must be the first step by providing added value for coal through downstream coal gasification methods where the pilot project will be held at PT Bukit Asam as a state-owned enterprise. Coal gasification will produce by-products in the form of char which allegedly still has energy potential. As an effort to recycle when that pilot project is going operation, this char is then used as raw material to make briquettes. In this preliminary research, using coal samples with seam variation from PT Bukit Asam and the gasification process produces some char. After char characterization result by proximate and ultimate analysis, it is found that char experiences an increase in Gross Calorific Value grades from 5,804 cal/gr to 6,183 cal/gr (seam A1), from 5,794 cal/gr to 6,281 cal/gr (seam A2), from $5,837 \mathrm{cal} / \mathrm{gr}$ to $6,320 \mathrm{cal} / \mathrm{gr}$ (seam B1) and from 5,898 cal/gr to $6,407 \mathrm{cal} / \mathrm{gr}$ (seam C) and a significant decrease in sulfur levels from $1.18 \%$ to $0.38 \%$ (seam A1), from $0,41 \%$ to $0.30 \%$ (seam A2), from $1.12 \%$ to $0.59 \%$ (seam B1) and from $1.19 \%$ to $0.69 \%$ (seam $\mathrm{C}$ ) and also a significant decrease of inherent moisture from $16.10 \%$ to $12 \%$ (seam A1), from $15.10 \%$ to $11.40 \%$ (seam A2), from $17.6 \%$ to $10.30 \%$ (seam B1) and from $14.8 \%$ to $9.9 \%$ (seam C). This result makes char potentially a raw material for solid fuels that are environmentally friendly.
\end{abstract}

Keywords: "Coal", "Gasification", "Char", "Solid fuel"

\section{INTRODUCTION}

Coal is one of the mining products included as one of the fossil fuels. Based on data British Petroleum (BP) Statistical Review of World Energy in $2021\left(70^{\text {th }}\right.$ edition), the proven reserves of Indonesian coal for anthracite and bituminous types are estimated at 23,141 million tons and 11,728 million tons for the subbituminous and lignite types. Meanwhile, the world level coal reserves amount for anthracite and bituminous types and sub-bituminous and lignite types is about 753,639 million tons and 320,469 million tons, respectively [1]. In addition, according to data from the pers release on the website of Indonesian Ministry of Energy and Mineral Resources in 2021, total coal reserves in Indonesia are estimated at around 38.84 billion tons [2], where in addition to proven coal reserves, Indonesia has another data as coal resources predicted at approximately 143.7 billion tons.
Indonesia's coal resources quality is quite varied in terms of calorific parameters, ash and sulfur content, total moisture, and other parameters. About $60 \%$ of Indonesia's coal is in the medium rank of calorific coal or around 5100-6100 kcal/kg ADB (Air Dried Basis), another $30 \%$ coal quality is categorized as low rank with calorific value $<5100 \mathrm{kcal} / \mathrm{kg}$ ADB), about $7 \%$ the coal quality is included in the high-rank category with calorific value $6100-7100 \mathrm{kcal} / \mathrm{kg} \mathrm{ADB}$ and only $2 \%$ of the coal was included in the very high-rank category with calorific value more than $7100 \mathrm{kcal} / \mathrm{kg}$ ADB) [3]. This difference in quality in a coal formation is often characterized by differences in layers (stratigraphy) that reflect differences in the age of the coal.

One of the South Sumatra basins containing coalbearing formations is the Muara Enim Formation [4] which there are several coal layers (coal strata or seam), with each coal seam having a thickness that is not always the same. In the Muara Tiga Besar area, part of 
Muara Enim Formation, several coal seams have been explored and included in the measured reserves, namely seam $A 1$, seam $A 2$, seam $B 1$, seam $B$, seam $C 1$, and seam $\mathrm{C} 2$ like in figure 1 below.
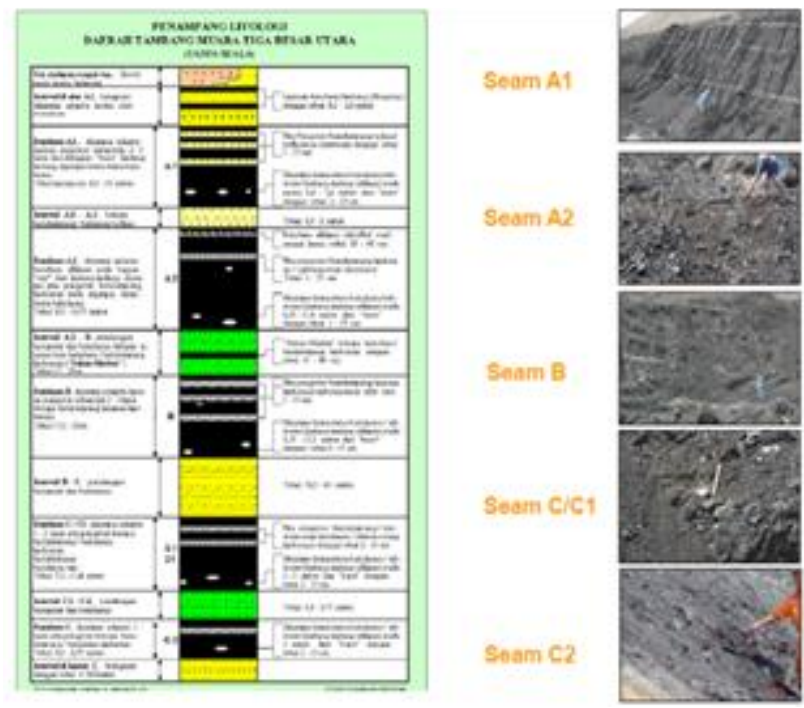

Source: Geology and Exploration. PT Bukit Asam.

Figure 1. Lithology Section of Muara Tiga Besar Formation

Steam Power Plant (PLTU) is one example of direct use of coal that is widely used in Indonesia and around the world, where coal is burned in boilers to generate heat that will be used to convert water into steam which is then used to drive steam turbines and turn generators to produce electrical energy. By-products in the form of gas flue and ash from burning coal cause increased levels of air pollution. Coal releases gases $\left(\mathrm{CO}_{2}, \mathrm{~N}_{2} \mathrm{O}\right.$, $\mathrm{NOx}, \mathrm{SOx}$, and $\mathrm{Hg}$ ) that cause global warming and pollution that currently become the world concern. Besides that, coal mining also pollutes the environment with coal mine wastewater, but with electrocoagulation technology using aluminum electrode this can be overcome [5]. Therefore, the use of clean and efficient coal remains a challenge that needs to be pursued extensively in the framework of decarbonization while extending the life of its availability (coal conservation). In addition, to minimizing global environmental burdens, one way to increase the utilization of clean coal is by the coal gasification process. [6][7][8]. Besides the direct combustion by being the raw material of the power plant, low rank coal can also be used as an environmentally friendly fuel by making it as briquettes. The manufacture of coal briquettes aims to utilize low grade coal also to reduce the pollutant content of coal that are harmful to the environment [9].

Briquettes are the process of mixing one or more mashed materials (such as sawdust, bean shells, coconut coir, palm oil, rice husks, corn cobs, bamboo, and other flammable materials) into solid compression materials due to pressure and often using starchy materials such as starch cassava. [10].
Table 1. Coal Briquette Quality Standards

\begin{tabular}{|l|c|c|c|c|c|}
\hline Briquettes & $\begin{array}{c}\text { Moisture } \\
(\%)\end{array}$ & $\begin{array}{c}\text { Volatile } \\
\text { Matter } \\
(\%)\end{array}$ & $\begin{array}{c}\text { Calorific } \\
\text { Value } \\
(\mathbf{C a l} / \text { gr })\end{array}$ & $\begin{array}{c}\text { Total } \\
\text { Sulfur } \\
(\mathbf{\%})\end{array}$ & $\begin{array}{c}\text { Breakin } \\
\text { g Load } \\
\mathbf{K g} / \mathbf{c m} \\
\mathbf{2})\end{array}$ \\
\hline $\begin{array}{l}\text { Lignite } \\
\text { carbonized }\end{array}$ & Max 20 & Max 15 & Min 4000 & Max 1 & Min 60 \\
\hline $\begin{array}{l}\text { Non-lignite } \\
\text { carbonized }\end{array}$ & Max 7.5 & Max 15 & Min 5500 & Max 1 & Min 60 \\
\hline $\begin{array}{l}\text { Egg-type } \\
\text { non- } \\
\text { carbonized }\end{array}$ & Max 12 & $\begin{array}{c}\text { according } \\
\text { to the coal }\end{array}$ & Min 4400 & Max 1 & Min 65 \\
\hline $\begin{array}{l}\text { Wasp nest } \\
\text { non- } \\
\text { carbonized }\end{array}$ & Max 12 & $\begin{array}{c}\text { according } \\
\text { to the coal }\end{array}$ & Min 4400 & Max 1 & Min 10 \\
\hline $\begin{array}{l}\text { Bio-coal } \\
\text { briquettes }\end{array}$ & Max 15 & $\begin{array}{c}\text { according } \\
\text { to raw } \\
\text { material }\end{array}$ & Min 4400 & Max 1 & Min 65 \\
\hline
\end{tabular}

Source [11]

To increase the added value of coal by turning it into solid fuel through briquettes, focusing only on increasing the calorific value is not enough, apart from the nature of coal, which has a lot of solid carbon, at the same time coal also has low volatile matter. This condition results in a high ignition temperature [12][13] Therefore, to anticipate this problem, coal briquettes will be added with biomass (agricultural/plantation waste). This is because the volatile matter content of the biomass is very high so that it allows ignition from low temperatures, which can then save the time and energy needed for ignition [12][14]. Efforts to make briquettes by mixing coal with biomass are called bio briquettes. Because it has a calorific value equal to the calorific value of coal and even exceeds it, coconut shell was chosen as an additive to increase the fuel value of bio briquettes [13]. Thus, in this study, the biomass that will be used as supporting material is a coconut shell, considering that this biomass has good thermal diffusion properties and can produce heat around 6500-7600 $\mathrm{kcal} / \mathrm{kg}$ [13][15].

The converting process from solid fuels or some hydrocarbon-containing materials such as coal and biomass into combustion-capable gases like $\mathrm{CO}, \mathrm{CH} 4$, and $\mathrm{H} 2$ with added a limited air supply (about $20 \%$ until $40 \%$ stoichiometric air supply) was known as the gasification process [16][17]. The difference between the gasification and pyrolysis process lies in the presence of air supply in the process. Biomass pyrolysis is commonly initiated from $300^{\circ} \mathrm{c}$ temperature to $600^{\circ} \mathrm{C}$ [17][18]. This process order and temperature are shown in figure 2 below. The product of pyrolysis generally depends on several factors, including pyrolysis temperature factor and also heating rate. In general, pyrolysis products can be classified [16]:

a. Solid products: rich in carbon content (char)

b. Liquid products: tar, hydrocarbons, and water

c. Gas products: $\left(\mathrm{CO}, \mathrm{H}_{2} \mathrm{O}, \mathrm{CO}_{2}, \mathrm{C}_{2} \mathrm{H}_{2}, \mathrm{C}_{2} \mathrm{H}_{4}, \mathrm{C}_{2} \mathrm{H}_{6}\right.$, $\mathrm{C}_{6} \mathrm{H}_{6}$, etc.). 


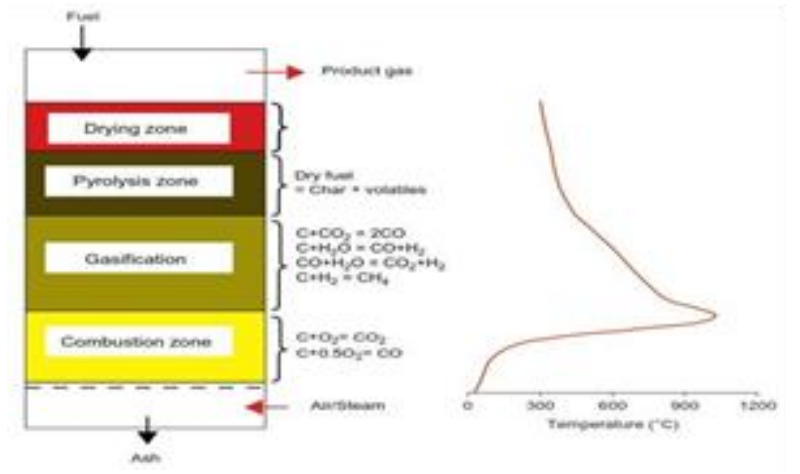

Source: [17]

Figure 2. Temperature Stages and Distributions in a Gasifier

The pilot project of coal gasification or down streaming coal to provide added value for coal in Indonesia will be held at PT Bukit Asam as a stateowned enterprise and has been confirmed in the law of the mineral and coal number 3 of 2020, mainly in article 102 paragraph 1 which is requiring for the mining industry to enhance the added value of minerals and coal which reads "IUP (mining license) or IUPK (special mining business license) holders at the production operation stage are required to increase the added value of minerals in mining business activities through: a) Processing and Purification of metal mineral mining commodities, b) Processing of non-metal mineral mining commodities, and c) processing of rock mining commodities" [19].

In the process of gasification, the desirable main product is syngas [12][20] that can be used in combined heat and power (CHP) engines. On the other hand, a byproduct called char, is obtained. Disposal management of char as residues from an industrial for future gasification plants is very important [12] because the accumulation of char in a certain period of time as a stockpile can have an effect on the environment [21]. From the results of the literature study, it is found that the char gasification result may have increased the carbon value so that it can be an initial hypothesis that char still contains energy potential and a significant decrease in sulfur levels. With the initial premise, therefore, in this study, the results of waste in the form of char become a potential raw material for the manufacture of briquettes. The manufacture of briquettes from coal is one form of utilization of coal into environmentally friendly energy. The use of char from the gasification process is an effort to reprocess/recycle waste gasification that has been done before. The gasification industry in the future will be one of the downstream coal programs [22], so that the use of charcoal gasification in the future will be one of the projects for the industry.

Research similar to this study has been carried out. The study was taken from several references to research on making briquettes using coal as the primary material, which has a character resembling char from gasification combustion, and other studies that use variations in the composition of coal and biomass raw material.

So, in general, what distinguishes the proposed research from previous research as a research renewal is, this study tries to characterize bio briquettes using char as a by-product of coal gasification (recycle) with variations in layers or stratigraphy of coal raw materials for gasification, with the addition of coconut shell charcoal. As a mixture of biomass, analyze the effect of the ratio of the two on the quality of the briquettes and the emissions produced in its combustion to obtain an environmentally friendly solid fuel.

This preliminary research focuses on characterizing char as a by-product of the gasification process using several types of PT Bukit Asam's coal from different stratigraphies, which are expected to reflect differences in properties and quality. Contribution to the mining industry, in this case, PT Bukit Asam, is converting coal into gas fuel and utilizing char waste as recycled from the gasification plant process to the next project by making briquette with biomass added.

\section{RESEARCH METHODOLOGY}

\subsection{Material}

The coal used in this study is taken from the Muara Tiga Besar mine site of PT Bukit Asam with seam variation: seam $A 1$, seam $A 2$, seam $B 1$ and seam $C$ at the coordinates of $3^{\circ} 43^{\prime} 16,315^{\prime \prime} \mathrm{LS}, 103^{\circ} 42^{\prime} 30,463^{\prime \prime}$, with mine brand MT 47 (4600 - $4800 \mathrm{kcal} / \mathrm{kg}$, ar).

\subsection{Coal Sampling}

Coal sampling at the mining front using the sampling method named the channel sampling or front sampling. Sampling carried out on coal seams that have been exposed, such as on walls or floors in mines. Sampling of the coal using an in situ sampling model without a scale, or it can be said that the manual sampling method is human as an operator, the tools used are scoops and plastic bags.

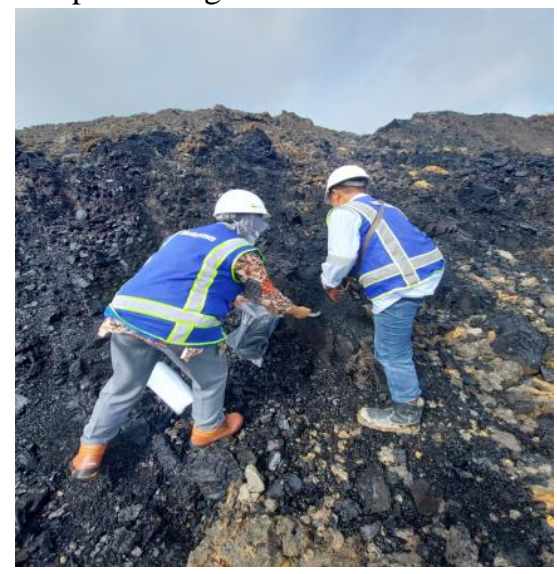

Figure 3. Coal Sampling Activity 


\subsection{Research Method}

In this research, there are two primary studies: the coal gasification process and the proximate and ultimate analysis in the laboratory of coal as a source of raw materials, char analysis of the by-products of coal gasification and as additional biomass coconut shells.

\subsubsection{Coal Gasification}

Procedures for obtaining char by coal gasification is the following steps:

1. The fuel used is coal obtained through outcrop sampling at the Muara Tiga Besar coal mining of PT Bukit Asam with seam variation. Before being used as a gasification raw material, this coal must be reduced in size to be incorporated into the reactor. Once the size is reduced, the coal is drained in the oven for 2 hours at room temperature. Coal that has been dried is put into an airtight plastic bag as much as $10 \mathrm{~kg}$ for one run.

2. Single Gas Outlet System Gasification Procedure. Put $10 \mathrm{~kg}$ of prepared coal into the reactor. Then burn with a flame igniter to start the combustion process. The air valve is left open, and make sure the valve on the syngas pipe is closed. The blower is turned on and fully opened the valve on the piping system. Wait \pm 10 minutes until the coal becomes coal. Then the pyrolysis process will occur, and the char to be used will be formed in this process.

3. Char that has been obtained is then separated and characterized to find out its initial quality.

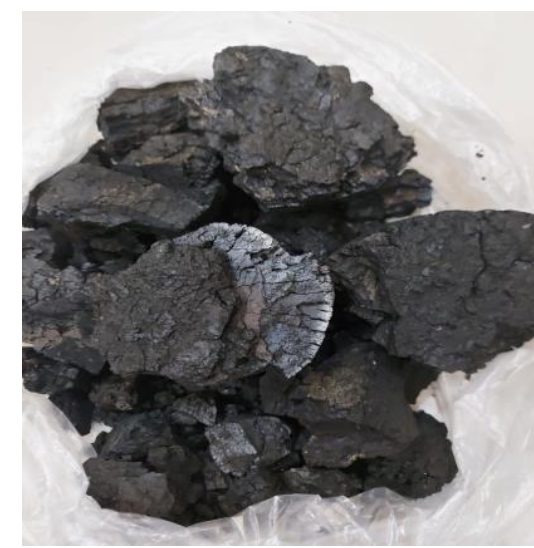

Figure 4. Char Side-Products of Coal Gasification.

\subsubsection{Proximate and Ultimate Analysis}

Before the gasification process is carried out, the coal is first carried out proximate and ultimate analysis to determine the content of the coal sample. After the gasification process is complete and char is obtained, it will then be carried out to laboratory for the following process, namely proximate and ultimate analysis. This characterization includes moisture, ash content, sulfur levels, volatile matter, fix carbon, and calorific levels.

1. Moisture

a. Weigh empty containers in advance

b. Put the sample in a container.

c. Put in a preheated oven from $104^{\circ} \mathrm{C}$ to $110^{\circ} \mathrm{C}$.

d. Heat the container containing the weight of the sample for \pm 1 hour.

e. Open the oven, and quickly close the dry weighing bottle and cool in a desiccator.

f. Immediately weighed it if it had reached room temperature.

g. Calculates the value of water content with the formula [13]:

Water Content $(\%)=\frac{m_{2}-m_{3}}{m_{2}-m_{1}} \times 100 \%$

2. Ash Content

a. Put the sample into the furnace, then heat it until the furnace reaches $700^{\circ} \mathrm{C}-750^{\circ} \mathrm{C} \pm 1$ hour or until all samples burn perfectly to ashes.

b. Lift the container from the furnace, place the lid on the cup and metal plate.

c. Cool for 10 minutes, then put in a desiccator.

d. Put the cold ash in the weighing cup and then calculate the ash level according to the formula. [13]:

Ash Content $(\%)=\frac{m_{3}-m_{1}}{m_{2}-m_{1}} \times 100 \%$

3. Sulfur Level

Sulfur levels are carried out using the Eschka Method, as follows: [13]:

a. Mixed $1 \mathrm{~kg}$ of the sample with 3 grams of Eschka.

b. Heat the sample into the furnace slowly until the temperature reaches $800 \pm 25^{\circ} \mathrm{C}$ for 1 hour. Heat at this temperature for \pm 1.5 hours until the mixture melts perfectly.

c. Cool the sample at room temperature, redissolve with $100 \mathrm{ml}$ of hot water in a $200 \mathrm{ml}$ chemical glass, heated into a hot plate for $1 / 2$ $3 / 4$ hour, stirring occasionally.

d. Filter it with filter paper and then wash with a material that does not dissolve with hot water. After several washes, transfer the material to filter paper and rewash it with hot water up to five times.

e. Dilute the filtrate with $250 \mathrm{ml}$ of methyl orange and neutralize with a solution of $\mathrm{NaOH}$ or $\mathrm{Na}_{2} \mathrm{CO}_{3}$, then add a solution of $\mathrm{HCl} 1 \mathrm{ml}$ (1:9), boiled and add $10 \mathrm{ml}$ or more of $\mathrm{BaCl}_{2}$ solution with a slow pipette while stirring.

f. Bring the solution back to be boiled for 15 minutes and let stand overnight. Then filtered with ash-free filter paper (Whatman filter paper 
no.42) and wash with hot water until the filtrate does not form mud when added agno 3 solution,

g. Put the sludge-filled filter paper into a porcelain cup which weight is already known, then burn it gradually in a furnace to a temperature of 800 .

h. Cool it in a desiccator, then weigh by using formulas [13]:

$$
\text { SulfurTotal Content }(\%)=\frac{\left(m_{1}-m_{3}\right) \times 13,738}{m_{1}}
$$

4. Volatile Matter

a. Put the sample in a sealed container, then heat it to a temperature of $900^{\circ} \mathrm{C}$ for 7 minutes.

b. Lift the container and leave it cool over a metal plate for 5 minutes, then put in a desiccator.

c. Once cool, then weigh and calculate volatile matter with the formula [13]:

$$
\text { Volatile Matter }(\%)=\frac{m_{2}-m_{3}}{m_{2}-m_{1}} \times 100 \%-M_{a d}
$$

5. Carbon Level

Fixed carbon is calculated using calculations of other types of proximate analysis, namely by subtraction of ash levels, water content, and levels of volatile matter.

Fixed Carbon $=100 \%-(\% \mathrm{M}+\% \mathrm{VM}+\% \mathrm{~A})$

6. Calorific Value

Calorific Value level can be determined using a Bomb Calorimeter. The steps are as follows:

a. Weigh 1 gram of sample into a cup.

b. Put it in a calorimeter bomb.

c. Put a $10 \mathrm{~cm}$ yarn burner on the wire connecting the two poles of the bomb head. Turn the yarn until the end touches the sample. The head of the bomb that already contains the sample is inserted into the Calorimeter bomb then rotates until it is closed and locked.

d. Press "start" below, then "continue", enter the code name or sample ID, and then press enter, see the bomb ID, adjust the bomb head code, then press enter and type the weight of the sample and then automatically the tool will analyze the sample and calculate it.

\section{RESULT AND DISCUSSION}

This paper discusses the result of the characterization of coal samples from PT Bukit Asam with variation seam $A 1$, seam $A 2$, seam $B 1$ and seam $C$. then the coal sample is gasified to obtain by-products in the form of char. This char sample is then tested for proximate and ultimate analysis again to determine the changes after the coal sample undergoes the gasification process. The chemical changes that occur are depicted in the table below:

Table 2. Proximate Seam Coal Analysis Values

\begin{tabular}{|c|l|c|c|c|c|}
\hline \multirow{2}{*}{ No } & \multicolumn{1}{|c|}{$\begin{array}{c}\text { Proximate } \\
\text { Analysis }\end{array}$} & \multicolumn{4}{|c|}{ Coal Seam } \\
\cline { 3 - 6 } 1 & $\begin{array}{l}\text { Total Moisture } \\
(\%, \text { ar })\end{array}$ & 27.5 & 31.9 & 30.7 & 31.70 \\
\hline 2 & $\begin{array}{l}\text { Inheren Moisture } \\
(\%, \text { adb) }\end{array}$ & 16.1 & 15.1 & 17.6 & 14.80 \\
\hline 3 & $\begin{array}{l}\text { Ash Content }(\%, \\
\text { adb) }\end{array}$ & 1.30 & 1.10 & 2.60 & 1.30 \\
\hline 4 & $\begin{array}{l}\text { Volatile Matter } \\
\text { (\%, adb) }\end{array}$ & 40.6 & 39.20 & 40.9 & 40.00 \\
\hline 5 & $\begin{array}{l}\text { Fixed Carbon }(\%, \\
\text { adb) }\end{array}$ & 42.0 & 44.60 & 38.90 & 43.90 \\
\hline 6 & $\begin{array}{l}\text { Total Sulphur }(\%, \\
\text { adb) }\end{array}$ & 1.18 & 0.41 & 1.12 & 1.19 \\
\hline 7 & $\begin{array}{l}\text { Calorific Value } \\
\text { (Cal/gr) }\end{array}$ & 5,804 & 5,794 & 5,837 & 5,898 \\
\hline
\end{tabular}

Table 3. Ultimate Seam Coal Analysis Values

\begin{tabular}{|c|l|c|c|c|c|}
\hline \multirow{2}{*}{ No } & \multicolumn{1}{|c|}{$\begin{array}{c}\text { Ultimate } \\
\text { Analysis }\end{array}$} & \multicolumn{5}{|c|}{ Coal Seam } \\
\cline { 3 - 6 } & \multicolumn{1}{|c|}{ A1 } & A2 & B1 & C \\
\hline 1 & Carbon $(\%$, adb) & 61.36 & 60.96 & 58.95 & 61.72 \\
\hline 2 & $\begin{array}{l}\text { Hydrogen }(\%, \\
\text { adb) }\end{array}$ & 6.38 & 6.21 & 6.37 & 6.30 \\
\hline 3 & Nitrogen $(\%$, adb) & 0.81 & 0.80 & 0.76 & 1.02 \\
\hline 4 & Sulfur $(\%$, adb) & 1.03 & 0.86 & 1.12 & 1.19 \\
\hline 5 & Oxygen $(\%, a d b)$ & 30.16 & 30.93 & 31.33 & 29.67 \\
\hline
\end{tabular}

Table 4. Proximate Char Analysis Values Coal Gasification Results

\begin{tabular}{|c|l|c|c|c|c|}
\hline \multirow{2}{*}{ No } & \multirow{2}{*}{ Proximate Analysis } & \multicolumn{4}{|c|}{ Char Gasification from Seam } \\
\cline { 3 - 6 } & & $\mathbf{A 1}$ & $\mathbf{A 2}$ & $\mathbf{B 1}$ & $\mathbf{C}$ \\
\hline 1 & $\begin{array}{l}\text { Inheren Moisture } \\
(\%, \text { adb) }\end{array}$ & 12.0 & 11.4 & 10.3 & 9.9 \\
\hline 2 & $\begin{array}{l}\text { Ash Content (\%, } \\
\text { adb) }\end{array}$ & 0.70 & 1.70 & 3.70 & 7.60 \\
\hline 3 & $\begin{array}{l}\text { Volatile Matter (\%, } \\
\text { adb) }\end{array}$ & 40.0 & 41.5 & 42.7 & 41.7 \\
\hline 4 & $\begin{array}{l}\text { Fixed Carbon (\%, } \\
\text { adb) }\end{array}$ & 47.3 & 45.4 & 43.3 & 40.8 \\
\hline 5 & $\begin{array}{l}\text { Total Sulphur (\%, } \\
\text { adb) }\end{array}$ & 0.38 & 0.30 & 0.59 & 0.69 \\
\hline 6 & $\begin{array}{l}\text { Calorific Value } \\
\text { (Cal/gr) }\end{array}$ & 6,183 & 6,281 & 6,320 & 6,407 \\
\hline
\end{tabular}

Table 5. Ultimate Char Analysis Values Coal Gasification

\begin{tabular}{|c|l|c|c|c|c|}
\hline \multirow{2}{*}{ No } & \multirow{2}{*}{ Ultimate Analysis } & \multicolumn{4}{|c|}{ Char Gasification from Seam } \\
\cline { 3 - 6 } & & A1 & A2 & B1 & C \\
\hline 1 & Carbon $(\%, a d b)$ & 72.63 & 72.72 & 72.78 & 73.79 \\
\hline 2 & Hydrogen $(\%$, adb $)$ & 4.48 & 4.53 & 4.46 & 3.26 \\
\hline 3 & Nitrogen $(\%$, adb) & 1.15 & 1.11 & 1.75 & 1.82 \\
\hline 4 & Sulfur $(\%$, adb $)$ & 0.44 & 0.35 & 0.69 & 0.84 \\
\hline 5 & Oxygen $(\%, a d b)$ & 21.04 & 20.11 & 17.69 & 14.21 \\
\hline
\end{tabular}

From tables 2 and 3, the results of the proximate and ultimate analysis of coal with several seams are obtained, namely seams A1, A2, B1 and C while tables 4 and 5 show the results of the proximate and ultimate analysis of the char gasification results from coal from 
seam A1, seam A2, seam B1 and seam $C$ that have previously been analyzed. And from Figure. 5 below, the graph that describes the proximate value of all the coal seams that are sampled, it can be seen that the difference in seams does not provide a significant difference in levels.

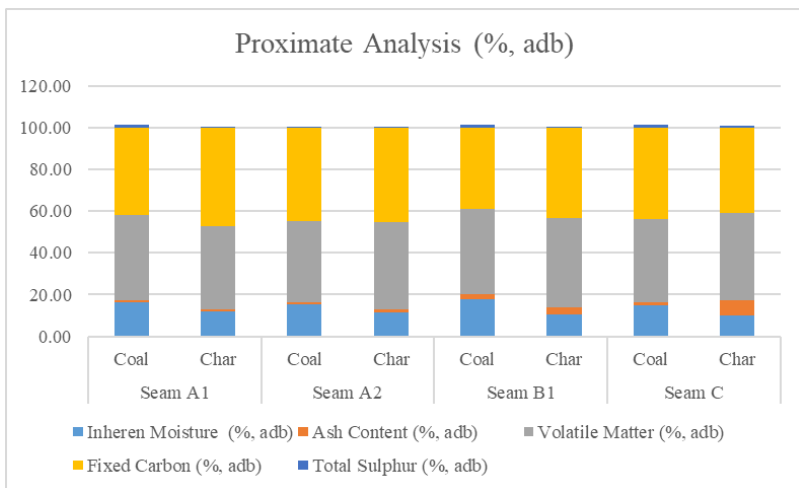

Figure 5. Proximate Analysis for All Seam

To make good and environmentally friendly briquettes, several critical indicators are needed: calorific value, sulfur content, water content and other indicators. The following is a graph that shows the difference in the chemical properties of the raw material of coal into char gasification results.

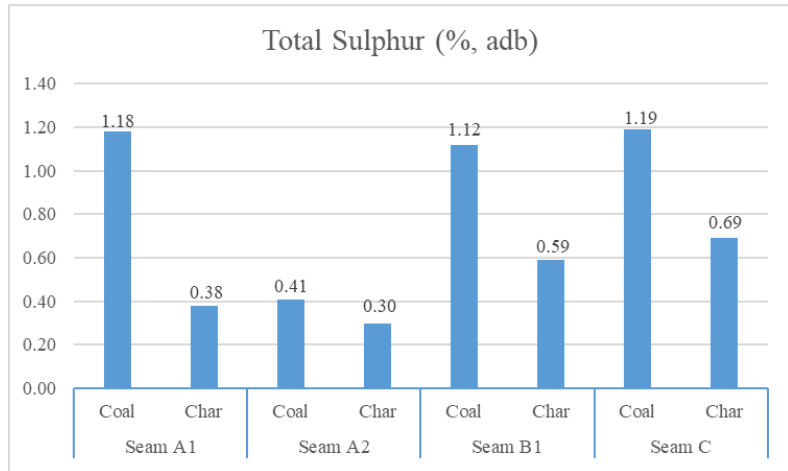

Figure 6. Analysis of Total Sulfur in Each Seam

Figure.6 above shows a significant decrease in sulfur content from each coal seam A1, seam A2, seam $\mathrm{B} 1$ and seam $\mathrm{C}$, where the most significant reduction occurred in seam A1. This significant decrease in sulfur levels from $1.18 \%$ to $0.38 \%$ (seam A1), from $0,41 \%$ to $0.30 \%$ (seam A2), from $1.12 \%$ to $0.59 \%$ (seam B1) and from $1.19 \%$ to $0.69 \%$ (seam $\mathrm{C}$ ). This shows that the gasification process reduces sulfur levels so that the char produced is safer for the environment.

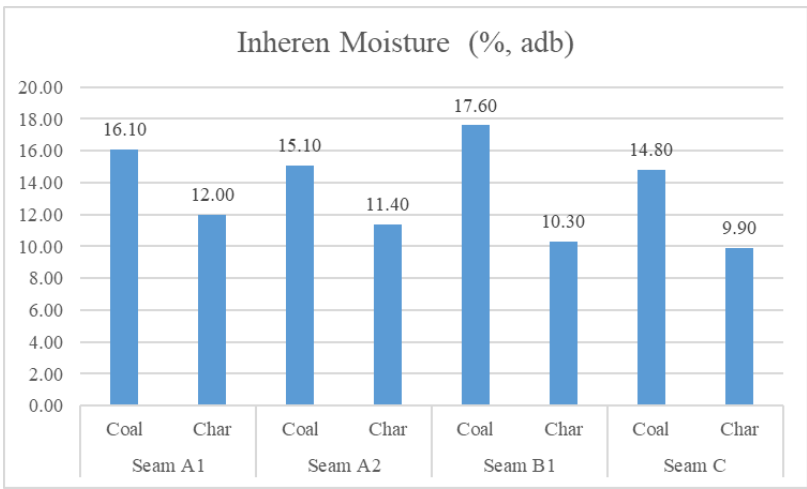

Figure 7. Analysis of Inheren Moisture in Each Seam

One indicator of a good briquette has low water content. The gasification process is generally proven to reduce water content significantly, making char an excellent raw material for briquettes. Significant decrease of inherent moisture in all seam are from $16.10 \%$ to $12 \%$ (seam A1), from $15.10 \%$ to $11.40 \%$ (seam A2), from $17.6 \%$ to $10.30 \%$ (seam B1) and from $14.8 \%$ to $9.9 \%$ (seam C).

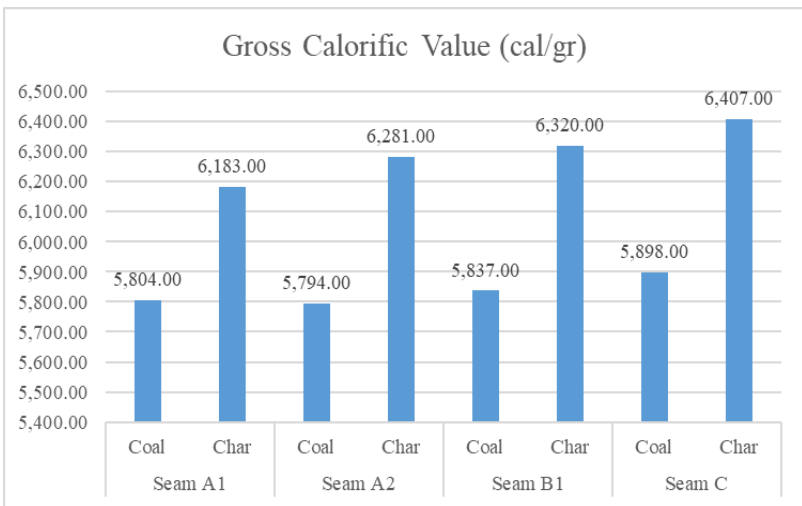

Figure 8. Analysis of Calorific Value in Each Seam

Table 6. Proximate Coconut Shell Analysis Value

\begin{tabular}{|c|l|c|}
\hline No & \multicolumn{1}{|c|}{$\begin{array}{c}\text { Proximate } \\
\text { Analysis }\end{array}$} & Coconut Shell \\
\hline 1 & Moisture $(\%$ adb $)$ & 5.8 \\
\hline 2 & $\begin{array}{l}\text { Volatile Matter } \\
(\% \text { adb })\end{array}$ & 18.2 \\
\hline 3 & $\begin{array}{l}\text { Ash Content } \\
(\% \text { adb })\end{array}$ & 0.04 \\
\hline 4 & $\begin{array}{l}\text { Total Sulfur } \\
(\% \text { adb })\end{array}$ & 73.9 \\
\hline 5 & $\begin{array}{l}\text { Fixed Karbon } \\
(\% \text { adb })\end{array}$ & 7,274 \\
\hline 6 & $\begin{array}{l}\text { Calorific Value } \\
(\text { cal/gr })\end{array}$ & \multicolumn{2}{|l}{} \\
\hline
\end{tabular}

Another indicator that is no less important is the calorific value, in Figure 8, it can be seen that there is an increase in the calorific value from the initial raw material of coal to char. An increase in gross calorific value grades from $5,804 \mathrm{cal} / \mathrm{gr}$ to $6,183 \mathrm{cal} / \mathrm{gr}$ (seam A1), from $5,794 \mathrm{cal} / \mathrm{gr}$ to $6,281 \mathrm{cal} / \mathrm{gr}$ (seam A2), from $5,837 \mathrm{cal} / \mathrm{gr}$ to $6,320 \mathrm{cal} / \mathrm{gr}$ (seam B1) and from 5,898 
$\mathrm{cal} / \mathrm{gr}$ to $6,407 \mathrm{cal} / \mathrm{gr}$ (seam C). This shows that the briquettes produced have the potential to have an excellent calorific value, especially when added with coconut shell biomass, as in the table. 6 above where it can be seen that the calorific value of coconut shell charcoal is very high with low water content, so it is hoped that the addition of this coconut shell will increase the calorific value of the briquettes that will be produced.

\section{CONCLUSION}

From the results of the proximate and ultimate analysis of coal before gasification and char gasification results side result, obtained an increase in gross calorific value from each coal seam and a decrease in the total sulfur value and inherent moisture of each coal seam. After char characterization result by proximate and ultimate analysis, it is found that char experiences an increase in Gross Calorific Value grades from 5,804 $\mathrm{cal} / \mathrm{gr}$ to $6,183 \mathrm{cal} / \mathrm{gr}$ (seam A1), from $5,794 \mathrm{cal} / \mathrm{gr}$ to $6,281 \mathrm{cal} / \mathrm{gr}$ (seam A2), from $5,837 \mathrm{cal} / \mathrm{gr}$ to 6,320 $\mathrm{cal} / \mathrm{gr}$ (seam B1) and from $5,898 \mathrm{cal} / \mathrm{gr}$ to $6,407 \mathrm{cal} / \mathrm{gr}$ (seam C) and a significant decrease in sulfur levels from $1.18 \%$ to $0.38 \%$ (seam A 1 ), from $0,41 \%$ to $0.30 \%$ (seam $\mathrm{A} 2$ ), from $1.12 \%$ to $0.59 \%$ (seam B1) and from $1.19 \%$ to $0.69 \%$ (seam C) and also a significant decrease of inherent moisture from $16.10 \%$ to $12 \%$ (seam A1), from $15.10 \%$ to $11.40 \%$ (seam A2), from $17.6 \%$ to $10.30 \%$ (seam B1) and from $14.8 \%$ to $9.9 \%$ (seam C).

Where the stratigraphic differences have no significant effect to characteristics of coal and char, this can be seen from the results of the proximate and ultimate analysis which are not much different so that the general use of char from any seam can be carried out on coal from the Muara Tiga Besar mines of PT Bukit Asam. And with the addition of coconut shell charcoal is expected to increase the calorific value of the briquettes that will be produced.

This shows that the char gasification by-product which is considered an undesirable material has energy potential that can be developed into raw material for briquettes as a more environmentally friendly fuel than direct coal combustion. The char characteristics meet the requirements according to the standard table of briquette quality, where the minimum heat value is 4000 $\mathrm{KCal} / \mathrm{Kg}$, and the sulfur value is a maximum of $1 \%$. With this research, it is expected to be one of the solutions for utilizing char as gasification industrial waste in the future, especially at PT Bukit Asam.

\section{AUTHORS' CONTRIBUTIONS}

All of the author are involved in the process of coal sampling, gasification process, proximate and ultimate analysis. The first and corresponding author contribution is responsible for coal sampling, data processing and manuscript writing. The second author is responsible for gasification process and char handling. The third author is responsible for proximate and ultimate analysis.

\section{ACKNOWLEDGMENTS}

The authors would like to Head of the Magister Study Program, Head of the Chemical Laboratory and staff of the Sriwijaya State Polytechnic, General Manager of Tanjung Enim Mining Unit (UPTE) and the Senior Managers and Managers of PT Bukit Asam who have supported this research.

\section{REFERENCES}

[1] Statistical Review of World Energy July 2021, British Petroleum, UK. 2021

[2] https://www.esdm.go.id/id/media-center/arsipberita/cadangan-batubara-masih-3884-miliar-tonteknologi-bersih-pengelolaannya-terus-didorong(accessed 30 November 2021, 18:09 Wib)

[3] Munandar, A. Imam., Z. Aprilasani, Samputra \& P. Lindiasari., Industri Pertambangan di Indonesia. Jakarta. Bypass Publisher. 2018

[4] S. Gafoer, T. Cobrie \& J. Purnomo, Peta Geologi Lembar Lahat, Sumatera, Puslitbang Geologi, Bandung. 1986

[5] Rusdianasari, A. Taqwa, and Y. Bow, Treatment of Coal Stockpile Wastewater by Electrocoagulation Using Aluminum Electrodes, Advanced Materials Research Vol. 896 (2014) pp 145-148.

[6] A. Syarif, A. Aswan, I. Rusnadi, A. Fadhulullah, N. Azizah, Effect of Air Flow and Filter Variation on Coal Gasification Process with The Downdraft System. Jurnal Kinetika Vol. 11, No. 01 (March 2020): 36-44. Politeknik Negeri Sriwijaya, Palembang. 2020

[7] D. Vamvuka, Gasification Coal in a book: Clean Use of Coals. Low-Rank Coal Technologies, MultiScience Publishing Co. Ltd., 2000

[8] Julismi, Rusdianasari, A. Hasan, Syngas Underground Coal Gasification (UCG) Testing of In-Situ Type Lignite Coal and Fracture Type Coal, International Journal of Research in Vocational Studies (IJRVOCAS) Vol. 1, No. 2, August 2021 Print ISSN 2777-0168 | Online ISSN 2777-0141 | DOI prefix: 10.53893

[9] S.S Idris, M. I. Zailan, N. Azron, N.A Rahman, Sustainable Green Charcoal Briquette from Food Waste via Microwave Pyrolysis Technique: Influence of Type and Concentration of Binders on Chemical and Physical Characteristics, Int. Journal of Renewable Energy Development (IJRED). 2021

[10] O. J. Lawal, T. A. Atanda, S. O. Ayanleye \& E. A. Iyiola,. "Production of Biomass Briquettes Using 
Coconut Husk and Male Inflorescence of Elaeis Guineensis". Journal of Energy Research and Reviews 3(2): 1-9, 2019; Article no. JENRR.50112 ISSN: 2581-8368, Nigeria. 2019

[10]Permen ESDM No 047 Tahun 2006. “Tentang Pedoman Pembuatan dan Pemanfaatan Briket Batubara dan Bahan Bakar Padat Berbasis Batubara”. Jakarta. 11 September 2006

[11]P. Hwangdee, Chaiyan. Jansiri, S. Sudajan, K. Laloon, Physical Characteristics and Energy Content of Biomass Charcoal Powder, International Journal of Renewable Energy Research. Vol.11, No.1, March, 2021

[12] V. Benedetti, F. Patuzzi, M. Baratieri, Gasification Char as a Potential Substitute of Activated Carbon in Adsorption Applications. The 8th International Conference on Applied Energy - ICAE2016. Energy Procedia 105 (2017) 712 - 717. 2017

[13] M. Yerizam, M.M. Faizal \& Novia, Characteristics of Composite Rice Straw and Coconut Shell as Biomass Energy Resources (Briquette) (Case study: Muara Telang Village, Banyuasin of South Sumatra). International Journal on Advanced Science Engineering Information Technology Vol.3 (2013) No. 3 ISSN: 2088-5334. 2013

[14] Cui Quan and Ningbo Gao, Review Article: Copyrolysis of Biomass and Coal: A Review of Effects of Copyrolysis Parameters, Product Properties and Synergistic Mechanisms, Hindawi Publishing Corporation BioMed Research International Volume 2016, Article ID 6197867, 11 pages, http://dx.doi.org/10.1155/2016/6197867.

[15] S.S Idris, M. I. Zailan, N. Azron, N.A Rahman, Sustainable Green Charcoal Briquette from Food Waste via Microwave Pyrolysis Technique: Influence of Type and Concentration of Binders on Chemical and Physical Characteristics, Int. Journal of Renewable Energy Development (IJRED). 2021
[16] Basu, Prabir. Biomass Gasification and Pyrolysis Practical Design and Theory. Published by Elsevier Inc, 2010

[17] M. Trifiananto, Characterization of Updraft Coal Gasification with Variation of Equivalence Ratio, Institut Teknologi Sepuluh November, Surabaya. 2015

[18] Sarmidi, M. Yerizam, A. Syarif, Syngas Characteristics from UCG Gasification Process with Lignite and Subbituminous Coal Types, International Journal of Research in Vocational Studies (IJRVOCAS) Vol. 1, No. 2, August 2021. Print ISSN 2777-0168 | Online ISSN 2777-0141 DOI prefix: 10.53893

[19] Undang-undang nomor 3 Tahun 2020 tentang Perubahan Atas Undang-Undang Nomor 4 Tahun 2009 Tentang Pertambangan Mineral dan Batubara, 2020

[20]J. Lemana, A. Hasan, A. Syarif, Syngas Underground Coal Gasification (UCG) Testing of Fracture Type Subbituminous Coal in Laboratory Scale. International Journal of Research in Vocational Studies (IJRVOCAS). Vol 1, No 2, August 2021. Print ISSN 2777-0168| Online ISSN 2777-0141| DOI prefix: 10.53893

[21] Rusdianasari, S. Arita, E. Ibrahim, Ngudiantoro, Characteristic of Coal Stockpile in Lowland and the effect to Environment, Springer Series in Materials Science, Volume 204 in Recent Trends in Physics of material Science and Technology, 2015.

[22] A. Zulatama, A. Syarif, M. Yerizam, Effect of Oxygen Flow Rate on Combustion Time and Temperature of Underground Coal Gasification, International Journal of Research in Vocational Studies (IJRVOCAS) Vol. 1, No. 2, August 2021 Print ISSN 2777-0168 | Online ISSN 2777-0141 | DOI prefix: 10.53893 